\title{
MULHERES EVOLUÍDAS: O DISCURSO PUBLICITÁRIO E SUA IDEOLOGIA
}

\author{
Mérli Leal Silva ${ }^{1}$ \\ Juliana Zanini Salbego ${ }^{2}$ \\ Universidade Federal do Pampa, São Borja, RS
}

\section{RESUMO}

Este artigo tem como objetivo analisar o discurso publicitário da campanha da Bombril mulheres evoluídas - como espaço ideológico de produção de sentido, a partir de reflexão teórica sobre a construção da identidade de gênero nas mídias.

Palavras chave: gênero; propaganda; ideologia.

\section{RESUMEN}

Este artículo pretende analizar el discurso de campaña publicitaria "Bombril - Mulheres evoluídas" - como espacio ideológico para la producción de sentido, de reflexión teórica sobre la construcción de la identidad de género en las noticias.

Palabras clave: el género; propaganda; ideología.

\begin{abstract}
This article intend to analyze the discourse's publicity campaign "Bombril - Mulheres Evoluídas" - as ideological space for production of meaning, from theoretical reflection on the construction of gender identity in the news.
\end{abstract}

Keywords: gender; propaganda; ideology.

Os meios de comunicação de massa são espaços de poder e disputa social. Uma determinada visão de mundo é traduzida em produtos culturais de toda ordem e de forma orquestral. Sobrevive então a norma e o sentido que vence a disputa. Para vencê-la, os investimentos simbólicos são grandes e profícuos. Mas, afinal, que poder tem um discurso? De onde vem tanto poder, e como podemos desvelá-lo? Todo discurso está no interior de um sistema de formações sociais. Quando falamos em discurso da comunicação de massa, nos referimos a um conjunto complexo de formações sociais. Neste sentido, discurso e ideologia não podem ser separados, pois o sentido será determinado a partir da relação entre ambos. $\mathrm{Na}$ verdade, o efeito de sentido existe porque existe ideologia em seu interior. Segundo Orlandi, 
[...] a ideologia não promove ocultação, nem engano, mas produz o desconhecimento de sentidos através de processos (históricos) discursivos cuja materialidade (lingüística) podemos observar ou discernir. Ou seja, podemos compreender a ideologia como o fato de que os sentidos são fixados historicamente em uma direção determinada (ORLANDI, 1983, p.103).

Tais sentidos, acrescenta a autora, resultam da produção de certo imaginário, ou seja, de uma interpretação que aparece como necessária e que destina sentidos fixos para as palavras, num certo contexto sócio-histórico. Portanto, as formas de organização dos gêneros em nossa sociedade estão alicerçadas na cultura, que ratifica o poder masculino e a submissão feminina.

A campanha da Bombril - mulheres evoluídas, criada pela DPZ para veiculação nacional desde o dia 8 de março de 2011, tem características de produção conectada com uma ideologia de poder e submissão. Na verdade, o chiste que a campanha veicula pode ser considerado de mau gosto e um desserviço aos estudos de gênero. O círculo vicioso dos anúncios com preconceito de gênero parece sempre retornar aos meios de comunicação. As campanhas avançam e logo se reduzem ao senso comum. Não é novidade que a publicidade brasileira tente comemorar o Dia Internacional da Mulher com argumentos que nada tem a ver com as conquistas do gênero nas últimas décadas. Beleza, magreza e consumo tem sido, a exemplo de anúncios de empresas de cosméticos especialmente, tem dado o tom de como a publicidade representa a mulher no contexto contemporâneo.

Para poder fugir deste círculo vicioso, consideramos importante analisar a visão de Morin (1988) em relação à cultura e à sociedade: se podemos conceber o complexo das liberdades, também podemos compreender que a cultura seja tanto libertação como prisão para o conhecimento ou para o pensamento. A cultura aprisiona-nos nos seus imperativos e proibições, nas suas normas e normalizações, nas suas limitações e ocultações. Mas, ao mesmo tempo, a cultura oferece-nos uma linguagem, um saber, uma memória, uma comunicação, uma possibilidade de trocas, verificações, refutações. Quando ela comporta em si a pluralidade dialógica e a abertura em relação às outras culturas e aos saberes exteriores, oferece-nos a possibilidade de libertar-nos, de forma relativa, das suas limitações e das suas ocultações. Mas como se estruturam as questões relativas às lutas das mulheres em relação à construção de um espaço social? 


\section{A Construção de um Espaço Social}

A ocupação de um espaço social pelo elemento feminino tem acontecido sempre dentro de uma proposta de concessão de poder do universo masculino. As mulheres são, tão somente, o que os homens não são. Isto é: são dependentes e, pela mesma razão, nãoagressivas, embora nutridoras; não-públicas, mas privadas. O mundo das mulheres é constituído por uma série de negações - elas são simplesmente o que acontece não ser. Entretanto, pela maternidade, a mulher pode aprender a se relacionar com o outro de um modo não-dominador, sem cair na armadilha de renunciar à sua própria identidade.

O macho narcisista a considera como sendo exatamente ele mesmo, ao seu oposto. E, para esta ótica, colabora a própria constituição de uma esfera de discurso que bane a mulher da história, empurrando-a para o domínio da natureza, da luz do público para o interior da casa, do efeito civilizador da cultura para o repetitivo fardo de reproduzir, nutrir e cuidar. A esfera pública - a esfera do que consideramos justiça - dá-se na historicidade, ao passo que a esfera privada, do cuidado e da intimidade, dá-se de forma atemporal, e a esfera histórica é imutável e interminável. A desistoricização do domínio privado significa que, enquanto o ego masculino celebra sua passagem da natureza para a cultura, do conflito para o consenso, as mulheres permanecem num universo interminavelmente igual, condenadas a repetir os ciclos da vida. Sem dúvida, a legitimação destas concessões passa pelo universo da linguagem e, no caso da comunicação, pelo universo dos discursos sociais.

Dentro do contexto social no qual a mulher está inserida, que tipo de discurso ela está autorizada a usar? Que estatutos são estabelecidos para que a mulher possa proferir este ou aquele discurso? Em nossa sociedade estas questões já estão estabelecidas: a linguagem é uma questão de gênero. "Isto uma mulher não deve dizer!" "Isto é jeito de falar de homem." Quantas vezes estes comentários passaram despercebidos pelos nossos ouvidos? O direito de proferir um discurso é regulamentar, juridicamente estabelecido, e é aceito, ou não, considerado, ou não, sempre levando em conta estas regras fundamentais que legitimam quem fala.

Outro fator básico na construção discursiva é o lugar de onde falamos. Este lugar também é instituído, também é carregado de ideologia. As mulheres possuem um espaço físico e social delimitado. Quando ouvimos falar que "lugar de mulher é na cozinha", temos, nesta expressão, um alto teor de implícitos e subentendidos. O lugar permitido para proferir discursos, enquanto mulher, é quase sempre o seu lugar institucional: o lar. Lar pode ser até mesmo o daquela mulher supermoderna, independente, realizada. De qualquer forma, esta 
mulher vai utilizar o discurso submetido à instância que lhe é franqueada: o discurso pedagógico, dentro da escola/universidade; o discurso culinário, dentro da cozinha ou adjacências; o discurso protetor, em todos os espaços que lhe exigem cuidados maternais. O próprio quarto acaba sendo um lugar de onde pode vir o discurso feminino, negociando com o homem no seu momento de descanso físico, com menos resistência para dizer-lhe não. Os lugares de onde está vindo o discurso feminino são ainda os lugares estabelecidos socialmente nos últimos anos. Falar fora destes lugares é ser contraventor de um sentido estabelecido. A sociedade trata as mulheres que falam fora dos lugares estabelecidos como exceções; e elas podem ser amadas ou odiadas por isto: Evita Perón, Madonna, Camile Paglia.

As posições que a figura feminina ocupa, a partir do seu discurso, estão relacionadas ao prestígio que esta figura tem, nos diversos domínios ou grupos de objetos. Dentro desta estrutura, a mulher que questiona, o faz segundo uma grade de interrogações, explícitas ou não, e fala segundo uma programação de informação fornecida pelos meios de comunicação. Assim, esta posição é culturalmente atribuída: até mesmo nossos questionamentos são socialmente engendrados. E se, também as emoções são artefatos culturais, como diz Geertz (1989), as posições que ocupamos ao proferirmos um discurso são sempre coodeterminadas pelas posições que a cultura nos instituiu. Todas as ações sociais possuem uma intertextualidade: vivem e se nutrem de relações com outros textos, outras estórias; nunca são únicas - são muito mais do que parecem. Assim, são as lacunas, os não-ditos, que nos mostram como a figura feminina é realmente representada no contexto social. A cultura fornece o vínculo entre o que os indivíduos são capazes de se tornar e o que eles realmente se tornam, e é interpretando o fluxo do discurso social que é possível realmente descobrir estes véus.

Algumas vezes a identidade social desaparece completamente, dando lugar a um papel abstrato. Por exemplo, a comunicação publicitária: de um lado uma instância complexa, do ponto de vista econômico, que se configura no papel de anunciante; e, de outro, alvos diferentes, configurados no papel de consumidor. E o mediador - o redator das mensagens publicitárias -, o operador das estratégias linguageiras? Muitas vezes ele é um sujeito sem poder real e, até mesmo, sem poder aquisitivo; mesmo assim, é investido de poder: poder de influenciar, de persuadir, como os líderes, representando uma entidade muito mais poderosa do que ele, indivíduo. É neste processo que o produtor perde sua identidade social.

Para Charaudeau (1996), todo ato de linguagem confirma o resultado de duas atividades: a de produção e a de interpretação. Ambas se processam em uma mise en scéne 
discursiva da qual participam quatro protagonistas: o Eu Comunicante, o Eu Enunciador, o Tu Interpretante e o Tu Destinatário.

O primeiro, sujeito responsável pela produção, afetado por um certo status psicossocial, tem um projeto de fala e se engaja numa interação com um protagonista; o protagonista institui-se como o Sujeito Interpretante (leitor), também portador de um certo status social que endossa a relação de troca que lhe é proposta. Entretanto, como estes não são seres da fala, a eles associam-se o Sujeito Enunciador (editores e repórteres) e o Sujeito Destinatário (público leitor em geral). Temos, assim, o encontro de dois universos linguísticos: o circuito externo, que é o lugar das condições de produção e de interpretação da linguagem - onde são postos em cena os Sujeitos Comunicante e Interpretante - e o circuito interno, que é o lugar do Dizer - onde são postos em cena os Sujeitos Enunciador e Destinatário, responsáveis pela instância do Fazer, como seres da fala.

Neste cenário, constrói-se o contrato de comunicação, responsável pela organização da matéria linguística nos seus vários modos: discursiva-enunciativa, narrativa, descritiva e argumentativa. Este contrato de comunicação pressupõe a obediência a um princípio básico: o direito à palavra, que um parceiro deve conceder ao outro para que se processe o jogo comunicativo, que decorre do reconhecimento da capacidade do saber, do poder e do saber fazer do Sujeito Comunicante, responsável pela legitimidade e credibilidade de suas ações. Para completar o quadro enunciativo, exige-se um saber compartilhado, que pode ser de ordem linguística, experiencial ou interdiscursiva.

O Sujeito Comunicante constrói, assim, sua mensagem através de "estratégias" discursivas, o que equivale dizer, baseando-se em Charaudeau (1996), que comunicar é usar estratégias e interpretar é saber reconhecê-las. Na verdade, a linguagem é múltipla e opaca; sempre se diz mais ou menos do que se pretende. Logo, não se pode esquecer o implícito, a inferência e a pressuposição presentes em qualquer texto.

Outra ilusão diz respeito ao fato de a linguagem ser uma tradução linear do pensamento. Sabe-se que todo ato comunicativo é negociado: resulta de uma co-construção de sentido, no instante da interação. Por isto, considera-se toda mensagem como resultado de uma operação interativa, na qual devem ser levadas em conta as condições de produção do texto e o reconhecimento da intenção dos sujeitos envolvidos. A presença feminina na cultura capitalista moderna vem se fortalecendo cada vez mais, afetando homens e mulheres, indistintamente. Uma das consequências disto é que, desde o final dos anos 60, o movimento feminino, no ocidente, vem discutindo políticas de produção de sentido. Assim, as maneiras 
como as mulheres são representadas em anúncios, na mídia, têm sido objeto de ataques, debates, questionamentos.

Resgatando o simbólico, já no início da vida, observamos que a mãe não é apenas a primeira mulher, mas também a primeira representante do mundo que encontramos. A simbolização, até agora culturalmente universal, da terra como uma mulher, capta essa conexão entre nosso relacionamento com a mãe e nosso relacionamento com a natureza. A natureza, em síntese, torna-se mãe-natureza, porque é a mãe que alimenta. Sob certas condições dessa alimentação, a hostilidade que acompanha seu término é traduzida em hostilidade para com a natureza que a mãe representa. Se a dominação da natureza é a dominação da mãe, o poder maternal continua instaurado e é apenas substituído por um poder maior e imperceptível, fazendo com que o sujeito não o perceba. Não perdendo esse poder, o sujeito não consegue eliminá-lo. Assim, tal poder segue inalterado, reproduzindo todas as tendências políticas autoritárias em cuja erradicação estava ostensivamente engajado. Daí a dura conclusão foucaultiana: "imaginar outro sistema é ampliar nossa participação no atual sistema" (FOUCAULT apud BENHABIB; CORNELL, 1987, p.126).

As mulheres, portanto, não sobrevivem exclusivamente graças aos poderes reconhecidamente femininos, mas também em função da luta que travam com os homens pela ampliação-modificação da estrutura do campo de poder. Como na dialética (escravo e seu senhor), homem e mulher jogam. Cada um com seus poderes: o homem para preservar sua supremacia; a mulher para tornar menos incompleta sua cidadania. Só se pudermos compreender por que a voz das mulheres foi silenciada, e como os ideais dominantes de autonomia em nossa cultura, bem como a definição privilegiada de esfera moral continuam a silenciar as vozes das mulheres, podemos, de fato, ter esperança de mudar para uma visão mais integrada de nós mesmos e de nossos semelhantes humanos como outros generalizados e outros concretos.

Para explicar a opressão das mulheres é preciso revelar o poder dos símbolos, mitos e fantasias que enredam ambos os sexos no mundo inquestionado dos papéis dos gêneros. Talvez o mais importante destes mitos seja o ideal de autonomia concebido à imagem de um ego masculino desimpedido. Essa visão de autonomia foi, e continua sendo, a base sobre a qual uma política implícita, que define a esfera íntima doméstica como histórica, inalterável e imutável, cresceu, com isso, afastando-a da reflexão e da discussão.

Visto como a construção de gênero afeta a todos, em nossas instâncias de poder e liberdade, cabe agora analisarmos um pouco a constituição do discurso publicitário, objeto principal do nosso estudo. 


\section{Produzindo Sentidos no Discurso Publicitário}

O discurso publicitário é um objeto multidimensional. O sujeito que produz este objeto, por definição, não pode ser um sujeito que tenha controle sobre todos os seus níveis de determinação, que estão neste objeto. Segundo Verón (1979), a linguagem não é um instrumento, porque ninguém que fala controla a linguagem.

Mediante processos de linguagem, a mídia não só determina, mas engendra seu referente; isto é, ela pensa e constrói o objeto de que fala. Ela se constitui, assim, numa espécie de mediação de um real que se passa em outro plano (imaginário) e noutro momento, diferente daquele do objeto cultural, da ideia, do valor ou do serviço de que se fala. Seu discurso é uma fala sobre. Dessa forma, o que resulta é um processo de produção de sentido, o desenvolvimento de um modo de codificação. Isto significa que se deve compreender o discurso publicitário não apenas como um conjunto de signos, uma mensagem, mas um dispositivo mais complexo, cujas regras e inteligibilidade dependem daquilo que é imposto pela feição específica do meio, como uma ideologia, no interior da qual se constrói o discurso.

Nessa acepção, a publicidade tem maneiras próprias para produzir a noção de realidade. Seu trabalho de construção discursiva leva a uma exclusividade no sentido da construção deste discurso. É assim que o discurso publicitário marca as diferenciações sociais no modo de informação - no qual se organizam as regras que regem os contratos de leitura, que se dão no nível dos textos e das imagens -, tratando de construir a noção de receptor no próprio nível da produção.

Os operadores produtores de sentido são intertextuais, estão sempre no interior de diversos universos discursivos. Para analisar estes universos discursivos, no caso, o anúncio selecionado para este artigo, vamos utilizar a análise formal ou discursiva, realizando aquilo que Thompson (1995) denomina de leitura semiótica, mais adequada para conteúdos do universo publicitário.

\section{Os Operadores de Sentido nas Revistas Femininas}

As revistas femininas se codeterminam; isto significa que seu corpo editorial remonta discursivamente uma história, ao longo deste tipo de publicação. Pesquisando a primeira revista dirigida ao público feminino no Brasil, no início dos anos 20, já encontraremos similaridades com as revistas femininas dos anos 90. As questões sociais mais emergentes em relação à figura feminina continuam semelhantes, apesar de todas as evoluções.

A intertextualidade vale para universos discursivos diferentes, ou seja, o discurso publicitário utiliza frequentemente outros universos discursivos para se legitimar: desde o 
discurso médico até o literário. No caso específico dos anúncios de produtos de beleza, o discurso do médico dermatologista é de extrema valia para cristalizar conceitos sobre beleza. Já no caso de campanhas utilizando várias mídias, as mensagens veiculadas na televisão, por exemplo, podem ser bem mais aprofundadas nos anúncios das revistas. A mensagem, então, é resgatada pelo veículo impresso, que explica melhor o que pode ter ficado obscuro no discurso de 30 segundos da TV.

Outro operador de sentido são os textos mediadores, de códigos diferentes dos que determinam o discurso da produção de que participam. Estes podem, também, incluir outros significantes que não aparecem no discurso produzido por eles. Um exemplo são os releases sobre produtos de beleza: em princípio, eles nos passam a sensação de apenas nos darem informações imparciais sobre o assunto; algumas páginas após, no entanto, encontramos o anúncio de um produto específico para sanar o problema levantado no release anterior.

Nesta categoria, temos aquilo que Verón (1979) chama de "discurso oculto". Em publicidade, discursos ocultos seriam os layouts de um anúncio, a pré-produção de um comercial, o roteiro deste comercial, as marcações de cor de fotos, etc. Tais discursos ocultos, segundo Verón (1979), assumem um papel instrumental na produção de um dado objeto discursivo e constituem, por isso mesmo, um lugar privilegiado, em que transparecem alguns dos mecanismos ideológicos em ação na produção. Se assim se pode dizer, eles dependem de uma intertextualidade "profunda", pois são textos que, participando do processo de produção de outros textos, não atingem nunca, eles mesmos (ou muito raramente, ou por canais muito restritos), a consumação social dos discursos. Para Foucault (1972), discurso oculto seria o conteúdo latente ou virtual de enunciados, que multiplicariam o sentido deste discurso.

O discurso publicitário passa por um processo de produção, no qual temos um sujeito produtor e outro sujeito receptor, sendo que ambos são definidos pela posição social. O conjunto de determinações que define a posição social dos produtores de sentido é chamado de "condições de produção dos discursos".

Resgatando alguns conceitos, temos que "produção" são as operações de investimento do sentido nas matérias significantes, originando textos. Então, a leitura do processo de produção de um discurso está relacionada às suas condições de produção; a leitura é sempre um efeito de sentido. Quanto ao "discurso", o que lhe dá consistência é o conteúdo ideológico, considerando que todo o discurso é dotado de ideologia.

Assim, se analisarmos as condições de produção do discurso publicitário, teremos, primeiramente, o sistema de produção vigente: no capitalismo, a publicidade tem como função principal estabelecer relações de compra e venda de determinado produto ou serviço através de 
mensagens atraentes, sedutoras, contextualizadas, para um consumidor ideal, denominado "alvo". O universo do receptor, enquanto sujeito deste processo é de carência de alguma coisa; o universo do produtor da mensagem é de preenchimento desta falta. São lugares discursivos diferentes, que se articulam pela falta de algo e pelo preenchimento desta falta.

Em outra instância, observamos o discurso publicitário, que é da ordem do simbólico: perpassa pela linguagem e pela cultura, possuindo marcas próprias de seu funcionamento. $\mathrm{O}$ discurso pertence ao gênero ideológico, e cada formação ideológica constitui um conjunto complexo de atitudes e de representações que não são individuais, nem universais, mas que se relacionam mais ou menos diretamente a posições de classes em conflito, umas em relação às outras. Nesse sentido, o discurso publicitário, a partir das posições de sujeito que constrói, assegura a manutenção das relações de poder, no sentido apontado por Thompson (2005), garantindo certa cristalização das estruturas e relações sociais.

Para Verón (1979), ideológico é uma dimensão constitutiva de qualquer sistema social de produção de sentido. É possível perceber que tudo que entra na ordem discursiva vem de um lugar socialmente determinado. E para o discurso publicitário, isso não ocorre de forma diferente. Podemos, assim, compreender a forma pela qual todo e qualquer discurso publicitário adquire um fim social que transcende eminentemente o objetivo de venda, mas consolida, a partir de sua veiculação, uma posição quanto a valores e relações sociais. Quando o sujeito interno do discurso elege certo argumento apontando a mulher vencedora como aquela que mais se aproxima do estereótipo da virilidade masculina, não podemos compreender outra coisa se não a marca de um sujeito que fala de um lugar socialmente determinado: o lado da estrutura que se mantém intacta quando as relações sociais desiguais, tais como se apresentam, são preservadas.

$\mathrm{Na}$ trilha de Verón, vê-se que todo o discurso que se refere às mulheres tem, implicitamente, um contexto social pré-construído, marcado pela luta de classes e por uma problemática histórica fundamental: o que pode e o que deve ser dito para as mulheres e sobre as mulheres.

Percebemos que a produção do discurso publicitário tem a ver com a intencionalidade de um sujeito que pretende transmitir uma mensagem. Se o sujeito produtor só pode ser definido em termos de sua posição social, no trabalho de recepção temos esta posição também como fundamental. Portanto, ao decodificar uma mensagem, o receptor está entrando num sistema de regras, que obedece ao modo de funcionamento de uma sociedade. Não sendo o centro do dizer, dizemos conforme um contexto ideológico que nos cerca, e, conforme diz Althusser (1985), somos constantemente interpelados pela ideologia. 
O ideológico, então, não é apenas o nome de um tipo de discurso, mas é uma dimensão presente em todos os discursos produzidos no interior de uma formação social, na medida em que o fato de serem produzidos nessa formação social deixou traços nos discursos. São as marcas discursivas que nos dizem de onde vêm e para onde vão estes discursos, seus intertextos, seus não-ditos. A cada leitura, o texto é analisado, em sua integridade, coerência e contradições, pelo receptor.

Dentro desta análise, apresentamos uma questão fundamental para este estudo: para a mulher atual, a elevação da atividade econômica para esfera social pública e sua transformação em arena de sucesso, socialmente reconhecido, significa, simultaneamente, sua separação do lar e da família, situados agora num domínio privado e pessoal, atribuído naturalmente às mulheres como único lugar próprio de suas atividades? Contraditoriamente, foi através deste processo que se consolidou, acima de tudo, o lugar específico das mulheres (a casa), não apenas no sentido social, mas também no físico (espacialidade) - afinal, a dupla jornada está aí, instituída. E quando a própria dona da casa não executa "seu trabalho" doméstico, é obrigada a colocar outra mulher em seu lugar: a empregada.

Ao mesmo tempo, a manutenção da separação da mulher, em relação ao seu lar, tornou-se um dos principais testes para os homens, e um importante indicador, senão o componente principal, do seu sucesso social. Por quê? Porque a mulher que trabalha fora proporciona ao seu colega a oportunidade de, desempenhando a mesma função, ganhar mais, pois, socialmente, o homem ainda é considerado o provedor da família.

$\mathrm{Na}$ verdade, na prática, as mulheres nunca estiveram totalmente excluídas da atividade econômica fora de casa, mas, desde o início, foram levadas para um mercado de trabalho assalariado marginalizado. Assim é que os salários inferiores e a segregação das mulheres a um número limitado de ocupações de pouco prestígio reforçaram e consolidaram, ainda mais, sua atribuição do sistema família-casa, pelo menos como modelo desejável de prosperidade econômica e respeitabilidade social, concretizado por longo tempo na família de classe média. Isto, em última instância, privou a mulher de ser vista e ouvida durante muito tempo. O discurso que prevaleceu foi o discurso do ponto de vista masculino.

Assim, pelas suas condições sócio-históricas, a publicidade dos produtos de beleza também tem o viés masculino; e o que pode e deve ser dito sobre as mulheres o é, majoritariamente, a partir da leitura que os homens definem. Isto não se configura uma conspiração masculina, mas é resultado de um processo de engendramento discursivo altamente complexo e elaborado, com raízes ideológicas profundas. 
Neste sentido, é possível pensar a ideologia a partir da perspectiva de Thompson para o qual "estudar a ideologia é estudar as maneiras como o sentido serve para estabelecer e sustentar relações de dominação" (1995, p.76). Neste caso, o sentido da qual Thompson está interessado é aquele das formas simbólicas que estão inseridas nos contextos sociais e circulando no mundo social. "Por formas simbólicas, eu entendo um amplo espectro de ações e falas, imagens e textos, que são produzidos por sujeitos e reconhecidos por eles e outros como construtos significativos. Falas lingüísticas e expressões, sejam elas falas ou escritas, são cruciais a esse respeito" (THOMPSON, 1995, p.79). Contudo, este autor aponta que as formas simbólicas podem ser também não-linguisticas, em sua natureza, considerando as imagens e os combinados entre imagens, sons e palavras como matéria prima de análise. Nesta ceara, aponta que o processo ideológico aparece exatamente quando estas formas simbólicas são postas a serviço da manutenção das relações de poder. E, neste sentido, se grande parte dos discursos publicitários estão orientados a exaltar a posição do homem como superior ao da mulher, ou, o papel da mulher como ainda subserviente ao homem, é exatamente porque a preservação destas relações arcaicas e ultrapassadas ainda podem ser vistas como sustentáculo de uma sociedade, só aparentemente desenvolvida mas ainda bastante conservadora.

Para avaliarmos a importância desta questão, consideramos as colocações de Louis Quesnel (1974), segundo as quais a publicidade se assemelha à igreja e à escola, por sua importância social, por seu papel de formadora de opiniões. Mas, enquanto essas duas instituições parecem perder terreno na formação de mentalidades das sociedades modernas, a publicidade tem seu poder ampliado, sobretudo pela forma como usa a linguagem.

Como forma de classificar a mensagem publicitária, utilizamos a divisão proposta por Nelly de Carvalho (1996), pela qual podemos distinguir três planos: o identificador, o denotativo e o conotativo. O identificador consiste na própria identificação do gênero publicitário, ou seja, é a função classificatória da mensagem, baseada na necessidade de se reconhecer o caráter publicitário da informação; no plano denotativo está incluído o conjunto de informações inscritas no texto e na imagem. O aspecto linguístico preenche, assim, uma função semântica essencial: favorecer a inteligibilidade da proposição publicitária, desempenhando, junto com a imagem, um papel informativo. Por proposição publicitária entende-se, aqui, um grupo de conceitos integrados em uma unidade de potencial comunicativo capaz de transmitir algo a alguém. O aspecto linguístico também está ligado à determinação do receptor da mensagem, isto é, do público-alvo. O aspecto icônico, embora se preste também ao processo de simbolização, tem, acima de tudo, valor informativo. 
Coincide exatamente com o aspecto perceptível do objeto. Já o plano conotativo engloba as predicações adicionais, ou seja, a afirmação de qualidades exclusivas - que se inferem na denotação. Elas são o veículo da ideologia publicitária, modelando sua estética e sua psicologia. A finalidade da mensagem é alcançada quando o que se pretende transmitir é efetivamente transmitido e favorece uma certa disposição quanto ao referente: sua função é criar atitudes. O denotado tem sentido, mas não detém todo o sentido: há um segundo grau de significado, o conotativo, que introduz o plural e a subjetividade. É no aspecto linguístico que se concretiza o sentido da potencialidade libertária da imagem, uma vez que cabe ao texto escrito transformar o exotismo ou a poesia da imagem em apelo de compra. A real eficiência de uma mensagem publicitária só pode ser medida da compra do produto, ideia ou serviço.

\section{Dados da Campanha}

A Bombril quer dar uma "virada" na sua comunicação e aproveitou o mês da mulher para investir $\mathrm{R} \$ 40$ milhões em uma grande campanha publicitária com o objetivo de aproximar-se das consumidoras mais jovens e reforçar seu portfólio de 28 marcas, mostrando que a empresa é "mais que esponja de aço". A campanha inclui, pela primeira vez, a internet e apresenta o site www.mulheresevoluidas.com.br. No site, as comediantes Dani Calabresa, Marisa Orth e Monica Iozzi substituem Moreno e apresentam a AME, Associação das Mulheres Evoluídas. Na TV, as moçam apresentam todos os produtos da empresa - com exceção da esponja de aço. Segundo a Bombril, esta é a maior campanha da empresa e traz uma série de ineditismos: mulheres como protagonistas, consumidoras mais jovens como público-alvo e o reforço do diversificado portfólio da Bombril, que "vai muito além da esponja de aço".

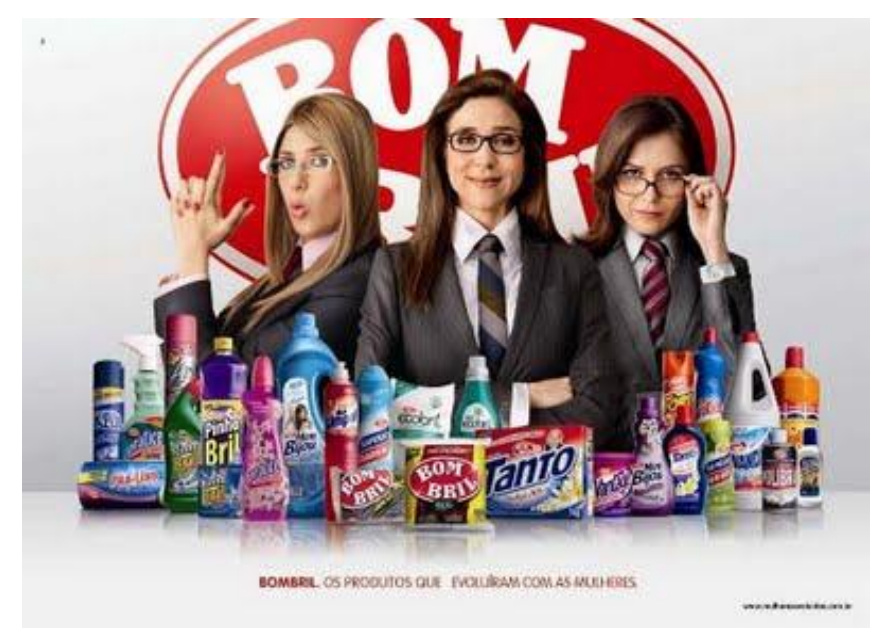

Figura 1: Bombril. Os produtos que evoluíram com as mulheres. Fonte: BOMBRIL, 2011. 


\section{Análise}

Aplicando o método da Investigação Hermenêutica de profundidade ao estudo do anúncio veiculado na revista Isto é, março 2010, analisaremos:

a) os modos típicos de apropriação dos produtos de comunicação de massa: o sistema midiático é construído considerando o receptor e suas referencialidades. Não basta ofertar mensagens, elas precisam ter sentido e fazer reverberar no inconsciente coletivo ações de concordância. No caso da publicidade, este sentido é ofertado através de sedução no formato das peças, inovação nas propostas de veiculação, enfim, um arsenal de possibilidades criativas direcionadas a fazer agir. A campanha mulheres evoluídas buscou a mídia televisiva como base em função do seu raio de cobertura nacional. E as revistas entram no sistema para segmentar o alvo. Há também o uso de um site para a campanha, com foco em consumidores mais jovens. Cada uma das mídias interage com o receptor para concretizar o contrato de leitura. Organiza-se, desta forma, a conexão entre meios de comunicação, produção de mensagens e recepção.

b) as características sócio-históricas dos contextos de recepção: a sociedade tem definido os papéis de gênero a partir da ideia de que há diferenças entre homens e mulheres e, por isso, haveria condição de separá-los por habilidades. Na verdade, as diferenças entre os gêneros é totalmente construída pela cultura. Tirando as diferenças biológicas, homens e mulheres se equivalem em talentos, habilidades, poder. Mesmo com evolução constante dos conceitos de gênero, as mulheres ainda são confinadas ao privado, ao cuidado, à ternura. Filhos e filhas são criados de forma diferente, e é na infância que os machos e as fêmeas são produzidos. Para as meninas, bonecas e panelinhas; para os meninos, carros e motos. Cruel, mas real! Dentro destas características, o comercial mostra uma evolução das mulheres altamente frágeis. Será que reproduzir o poder masculino significa evoluir? Ou seria a introjeção do homem dentro das mulheres em comportamentos e ações? Vestir-se como homem tornaria as mais mulheres? Difícil! Mas o anunciante corroborou com este chiste de péssimo efeito junto ao público feminino.

c) a natureza e significância das atividades de recepção: as mulheres evoluíram, fato incontestável. Na década de 20, nem votar podiam, hoje assumem a presidência da República. A cada dia as mulheres buscam mais espaço social e seguem lutando por igualdade. Mas os dados mostram que ainda ganham menos que os homens nas mesmas funções, sofrem com a tripla jornada de trabalho e são mais escolarizadas. Estudam mais, ganham menos e trabalham na rua e em casa ${ }^{3}$. Cada avanço social de gênero deveria ser contemplado com anúncios que 
naturalizassem a conquista feminina. Qual nada, a naturalização segue sendo de poder dos homens sobre as mulheres.

d) o significado das mensagens, como interpretado pelos receptores: esta campanha motivou a participação ativa dos consumidores. Homens reclamaram do tom agressivo e as mulheres reclamaram da linguagem da propaganda ter sido focada na reprodução/imitação do comportamento masculino pelas mulheres. O humor jocoso expõe, de forma pouco criativa, papéis cristalizados e pouco contextualizados para o mundo de hoje. Neste sentido, a propaganda da Bombril fere um princípio fundamental da propaganda: ter foco no públicoalvo. Se homens e mulheres sentem-se prejudicados pela imagem dos anúncios, algo não está correto, do ponto de vista estratégico.

e) a elaboração discursiva das mensagens comunicativas: o discurso publicitário da campanha foi elaborado buscando o mote do humor. Como conceito criativo, refere-se ao que se deseja comunicar, buscar uma abordagem adequada para contar a história do tema escolhido. O tema mulheres evoluídas proporciona um sem fim de abordagens. O problema, em nossa percepção, está na moral da história. O tema é bom, mas o tratamento dado a ele não foi adequado. A brincadeira não foi bem aceita pelos consumidores, os mesmos perceberam o ridículo das situações apresentadas, e ninguém saiu fortalecido pela proposta. No fundo, houve uma "involução" de todos os sujeitos envolvidos.

\section{Considerações Finais}

A discussão ora apresentada não é nova. O tema propaganda e gênero já vem sendo pesquisa há muito tempo e realmente muito pouco tem sido feito na prática para mudar a imagem de gênero nos conteúdos midiáticos. A sociedade mudou, a relação entre os gêneros evoluiu, mas isto não tem contado muito. Quando algo de novo acontece - como as propagandas publicitárias da Dove, por exemplo - acaba por tornar-se uma exceção! Todos comentam, acham ótimo, mas a propaganda segue igual: muitas vezes preconceituosa, ignorando a diferença, os avanços, os novos formatos de família, de vida. Um olhar histórico sobre o tema nos faz inferir que há muito o que fazer para mudar esta realidade discursiva.

Devemos refletir sobre a perspectiva de Kellner, para o qual devemos efetuar

“uma pedagogia crítica da mídia cujas finalidades são: possibilitar que os leitores e cidadãos entendam a cultura e a sociedade em que vivem, dar-lhes o instrumental de crítica que os ajude a evitar manipulação da mídia e a produzir sua própria identidade e resistência e inspirar a mídia a produzir outras formas diferentes de transformação cultural e social”" (KELLNER, 2001, p.20). 
Neste sentido, entendemos que seja necessário desenvolver uma consciência crítica mais aguçada quanto às responsabilidades na elaboração dos produtos midiáticos. A costumeira afirmação de que 'a publicidade é um simples reflexo da sociedade', justificativa comum para todo e qualquer produto da mídia, é perigosa e acaba por eximir os produtores da publicidade da responsabilidade de suas escolhas. Se representamos as mulheres como dependentes dos homens e 'evoluídas', ao tornarem-se semelhantes aos mesmos, não é simplesmente porque a sociedade se apresenta desta forma, mas uma re-apresentação, uma recriação das formas de conceber as relações sociais que, neste caso, desiguais e injustas, acabam por denegrir as conquistas que tão dolorosamente foram alcançadas pelas mulheres nas últimas décadas.

Uma propaganda libertadora, emancipatória e dialógica, na perspectiva freireana, pode fazer muita diferença na formação de novos sujeitos e de novas e justas relações sociais. A revolução dos costumes passa pela mudança também nos meios de comunicação social. Nas universidades europeias, gênero é tema presente em todos os cursos, como componente curricular. Há cartazes dentro do campus publicizando temas de gênero. Educação em forma de displays, cartazes, intervenções urbanas no campus. Há reflexo disto nas propostas de propaganda apresentadas. É possível encontrar reflexões sobre este tema no artigo "Propaganda e gênero - os invisíveis", no prelo. Cabe à Bombril repensar seu papel de anunciante mil e uma utilidades e focar no seu público-alvo de forma respeitosa e transformadora. Mostrar mulheres evoluídas, de verdade, que estão nem aí para limpeza da casa, que querem ser felizes.

\section{Referências}

ALTHUSSER, Louis. Aparelhos Ideológicos de Estado. Rio de Janeiro: Graal, 1985.

BENHABIB, Seyla; CORNELL, Drucilla. Feminismo como crítica da modernidade. Rio de Janeiro: Rosa dos Tempos, 1987.

BOMBRIL. Mulheres evoluídas. Disponível em:

<http://www.mulheresevoluidas.com.br/campanhatv> Acesso em: 20 jun. 2011.

CARVALHO, Nelly de. Publicidade, a linguagem da sedução. Rio de Janeiro: Ática, 1996.

CHARAUDEAU, P. Para uma nova análise do discurso. In: CARNEIRO, Agostinho Dias (org.). O discurso da mídia. Rio de Janeiro: Oficina do Autor, 1996.

FOUCAULT, Michel. A arqueologia do saber. Petrópolis: Vozes, 1972.

GEERTZ, Clifford. A interpretação das culturas. Guanabara: Koogan, 1989. 
IBGE. Disponível

em.<http://www.ibge.gov.br/home/presidencia/noticias/noticia_visualiza.php?id_noticia=171

7\&id_pagina=1 < acesso em 06 de julho de 2011.

KELLNER, Douglas. A Cultura da mídia. São Paulo: Edusc, 2001.

MORIN, Edgar. O paradigma perdido. Portugal: Europa-América, 1988.

ORLANDI, Eni Pulcinelli. A linguagem e seu funcionamento; As formas do discurso. 1. ed. São Paulo: Brasiliense, 1983.

QUESNEL, Louis. A publicidade e sua filosofia. In: PÉNINOU, George. Os mitos da publicidade. Petrópolis: Vozes, 1974.

THOMPSON, John. Ideologia e cultura moderna: teoria social crítica na era dos meios de comunicação de massa. Petrópolis: Vozes, 1995.

VERÓN, Eliseo. Produção de sentido. São Paulo: Cultrix, 1979.

\section{Notas}

${ }^{1}$ Professora universitária desde 1990, educadora popular, mestre em Comunicação pela PUCRS, doutora em Educação pela USP, professora adjunta da Universidade Federal do Pampa, em São Borja; busca unir educação popular e comunicação em projetos inovadores, e-mail: merlileal@ gmail.com.

${ }^{2}$ Mestre em Comunicação Midiática pela UFSM (2008) e Professora do Curso de Publicidade e Propaganda da Universidade Federal do Pampa - Unipampa - Campus São Borja. julianasalbego @ unipampa.edu.br.

${ }^{3}$ A partir da síntese de indicadores sociais 2010 publicada pelo IBGE percebemos que mesmo com maior escolaridade, as mulheres têm renda média inferior ao dos homens. De acordo com esta pesquisa, o total de mulheres ocupadas recebia cerca de $70,7 \%$ da renda média dos homens. "A diferença era ainda maior entre os mais escolarizados: as mulheres com 12 anos ou mais de estudo recebiam, em média, 58\% do rendimento dos homens com esse mesmo nível de instrução. Nas outras faixas de escolaridade, a razão era um pouco mais alta (61\%). Entre 1999 e 2009, as disparidades pouco se reduziram". Fonte: IBGE. http://www.ibge.gov.br/home/presidencia/noticias/noticia_visualiza.php?id_noticia=1717\&id_pagina=1 < acesso em 06 de julho de 2011. 